\title{
CATATAN HUKUM KRITIS PEMBIAYAAN SEKUNDER PERUMAHAN
}

\author{
Rahmi Jened* \\ Departemen Hukum Perdata Fakultas Hukum Universitas Airlangga \\ Kampus B Unair Jalan Dharmawangsa Dalam Selatan, Surabaya, 60286
}

\section{Abstract}

The existence of Secondary Mortgage Facility (SMF) in Indonesia is adopted from common law's tradition. It is not easy to adopt legal institutions derived from the common law tradition into our country that base on the civil law tradition. Furthermore, even though SMF has managed to solve mismatch and improve credit liquidity, hence there are some critical legal notes to SMF institution. This paper will discuss about the differences law and regulation of real property ownership, true sale for repurchase of loan and its secured transaction (mortgage) and the existence of Special Purpose Vehicle (SPV) between Common Law and civil Law tradition.

Keywords: SMF, real property, mortgage, true sale, SPV.

\section{Intisari}

Eksistensi lembaga Fasilitas Pembiayaan Sekunder Perumahan (SMF) di Indonesia diadopsi dari common law system. Tentu bukan hal mudah untuk mengadopsi lembaga hukum dari tradisi common law ke dalam tradisi civil law. Meskipun telah terbukti lembaga ini dapat mengatasi mismatch dan meningkatkan likuiditas KPR, namun ada beberapa catatan hukum kritis tentang Pembiayaan Sekunder Perumahan.

Makalah ini akan membahas perbedaan hukum dan aturan tentang kepemilikan tanah, jual putus untuk penjualan kredit dan hak tanggungannya serta eksistensi perusahaan kendaraan untuk tujuan khusus antara tradisi Common Law dan Civil Law.

Kata kunci: SMF, hak tanggungan, jual putus, SPV.

\section{Pokok Muatan}

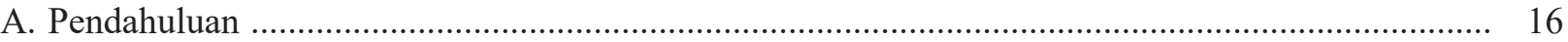

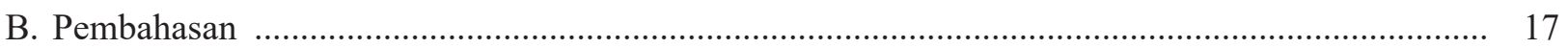

1. Hak Milik dan Hak atas Tanah serta Pembebanan Jaminan Hak atas Tanah .............................. 17

2. Sekuritas SMF: Jual Putus Penjualan Kredit dan Hak Tanggungannya .................................... 20

3. Eksistensi SMF sebagai Kendaraan untuk Tujuan Khusus (Special Purpose Vehicle/SPV) ...... 26

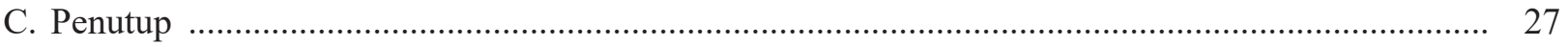




\section{A. Pendahuluan}

Krisis ekonomi tahun 1997 dan 2007 membawa dampak yang sangat berat bagi sektor perumahan (property) Pembiayaan sektor perumahan pada saat itu masih bergantung pada sumber pembiayaan jangka pendek, seperti deposito dan tabungan, sehingga mengakibatkan tingginya tingkat bunga pasar Kredit Pemilikan Rumah (KPR) yang akhirnya berpengaruh terhadap tingkat kemampuan masyarakat untuk membeli rumah yang layak dan terjangkau. Sedangkan bagi bank dengan kondisinya yang rentan saat ini dengan pembiayaan jangka pendek menimbulkan mismatch yang pada akhirnya membuat likuiditas bank semakin terpuruk. ${ }^{1}$

Secondary Mortgage Facility (SMF) mempertemukan dua kepentingan, yakni disatu sisi perbankan yang membutuhkan cash flow berupa dana jangka panjang untuk membiayai KPR, tetapi dana yang tersedia umumnya dana jangka pendek. Sementara itu, investor (perusahaan asuransi dan dana pensiun) mempunyai dana jangka panjang yang hanya ditempatkan pada instrumen investasi yang berjangka pendek. Malaysia dan Hongkong telah mengenal fasilitas ini lebih dari 30 tahun yang lalu dan berhasil menciptakan suku bunga KPR antara 9-10 \% per tahun. ${ }^{2}$ Lembaga SMF di Indonesia pada awalnya diatur dalam Surat Keputusan Menteri Keuagnan Nomor 132/KMK.014 Tahun 1998 (SK Menkeu RI No. 132/KMK.014/1998) Tanggal 27 Februari 1998 Tentang Perusahaan Fasilitas Pembiayaan Sekunder Perumahan.

Tanggal 22 Juli 2005 oleh Pemerintah mendirikan PT (Persero) Sarana Multy Griya Finansial (PTSMF) yang kegiatan usahanyanya adalah: (1) Program Sekuritisasi dengan cara memfasilitisasi transaksi sekuritisasi tahihan Kredit Pemilikan Rumah (KPR) milik penyalur KPR; (2) Program pembiayaan dengan cara menyediaan likuiditas pembiayaan jangka panjang/menegah bagi penyalur KPR dengan dana yang bersumber dari penerbitan Surat utang; (3) Program Pendukung dengan cara program penjaminan terhadap Efek Beragun Aset (EBA) KPR, penyediaan Pedoman dan Standar Dokumen KPR; dan (4) Program Pendidikan dan Pelatihan. ${ }^{3}$

Sebenarnya PT SMF terkait dengan peran Negara dalam upaya mewujudkan kesejahteraan social (social welfare). Menurut Rudhi Prasetya dengan mengutip Friedmann bahwa peran negara tersebut meliputi: (a) Provider; (b) Regulator; (c) Entrepreneur; dan (d) Umpire. ${ }^{4}$ Saat ini Pembiayaan Sekunder Perumahan diatur dalam Peraturan Presiden Nomor 1 Tahun 2008 Tentang Pembiayaan Sekunder Perumahan (Perpres No. 1/2008). Menurut Pasal 1 angka 11 Perpres No. 1/2008 dinyatakan bahwa: "Pembiayaan Sekunder Perumahan (sebagai terjemahan Secondary Mortgage Fasility- SMF) adalah penyelenggaraan kegiatan penyaluran dana jangka menengah dan/atau panjang kepada Kreditor Asal dengan melakukan Sekuritisasi”. Lebih lanjut 'sekuritisasi' menurut Pasal 1 angka 14 Perpres No. 1/2008 adalah: "Transformasi asset yang tidak liquid menjadi liquid dengan cara pembelian aset keuangan dari Kreditor Asal dan penerbitan Efek Beragun Aset (EBA)".

Kehadiran lembaga dengan Fasiltas Pembiayaan Sekunder Perumahan (Secondary Mortgage Facility/SMF) ini memudahkan pihak perbankan untuk membiayai sektor property. Sebagai lembaga pembiayaan baru yang timbul karena kebutuhan praktek dan lebih-lebih berasal

Erica Suroto, "Problema dan Solusi Sistem Secondary Mortgage Fasility", Seminar, Perusahaan Secondary Mortgage Fasility Sekunder Perumahan Sebagai Solusi Pembiayaan Jangka Panjang, Jakarta, 5 November 1998, hlm. 3.

Arie S. Hutagalung, "Problema dan Solusi Sistem Secondary Mortgage Fasility", Seminar, Perusahaan Secondary Mortgage Fasility Sekunder Perumahan Sebagai Solusi Pembiayaan Jangka Panjang, Jakarta, 5 November 1998, hlm. 3.

Direktur Utama PT Persero Sarana Multigriya Finansial, "SMF dan Perkembangannya", Materi Pelatihan, Aspek Hukum Pembiayaan Perumahan dan Sekuritisasi KPR, Kerjasama Program Magister Kenotariatan Fakultas Hukum Universitas Airlangga dengan PT SMF , Surabaya, 6-7 Desember 2014, hlm. 1.

Rudhi Prasetya dan Neil Hamilton, The Regulation of Indonesian Entreprises, Malaya Law Review, Volume 16, Nomor 2, Desember, 1974, hlm. 296-332, sebagaimana dikutip dari Lawrence Friedmann, Governmental Public Entreprise, tanpa penerbit, 1967, hlm. 4-8. 
dari tradisi Common Law ${ }^{5}$, maka perlu dikaji secara lebih mendalam Secondary Mortgage Facility $(S M F)$ ini agar sesuai dengan ketentuan tradisi Civil $L a w^{6}$ yang dianut oleh Indonesia. Beberapa catatan hukum dan kritik yang akan dibahas dalam artikel ini adalah perbedaan hukum dan aturan antara tradisi Common Law dan Civil Law tentang: (a) Hak Milik dan hak atas tanah serta pembebanan jaminan hak atas tanah Hak milik dan penguasaan tanah serta pembebanan jaminan hak atas tanah; (b) Sekuritisasi: Jual putus penjualan kredit dan hak tanggungannya; serta (c) Eksistensi perusahaan kendaraan untuk tujuan khusus.

\section{B. Pembahasan}

\section{Hak Milik dan Hak atas Tanah serta} Pembebanan Jaminan Hak atas Tanah

Terdapat fiksi hukum dalam tradisi hukum Common Law bahwa: "Tanah adalah milik Tuhan dan wakil Tuhan di muka bumi adalah raja".? Hukum yang berhubungan dengan benda-benda tetap adalah Real Property Law dengan fungsinya sentralnya dikaitkan dengan hukum kontrak, dan hukum yang berhubungan dengan benda-benda bergerak adalah Personal Property Law. Sedangkan menurut tradisi Civil Law Hukum Benda merupakan ajaran hukum tersendiri dimana dikenal pembagian Hukum Benda ${ }^{8}$ yang mengelompokkan benda tetap dan benda bergerak dalam satu Hukum Benda yang diatur dalam Buku II Burgerlijk Wetboek (BW). ${ }^{9}$
Dilihat dalam tradisi Common Law dari sejarahnya, masyarakat feudal di Inggris ditandai dengan adanya benda tetap bagi salah satu pihak yaitu Land Lord. tidak dikenal hak milik (eigendom $)^{10}$ sebagai pengertian tradisiCivil Law. Kemudian pemakaian benda tetap ini diserahkan kepada pihak lain yaitu 'Tenant yang diartikan sebagai:" in a broader sense one hold who holds or posssess in land or tenenency by any kind of rights or titles whether in fee, for life, for years, at written or otherwise" ${ }^{11}$ Dengan imbalan jasa-jasa tertentu yang dilakukan oleh "Tenant" yang menduduki tenure (masa jabatan) tertentu terhadap Land Lordnya. Dalam tradisi Civil Law mirip dengan penyewa (huurer). ${ }^{12}$ Tenure terdiri dari 2 (dua) macam yaitu: (a) Free tenure; dan (b) Non-Free Tenure. ${ }^{13}$

Free Tenure masih bisa dibedakan menjadi berbagai macam jasa, seperti, knight service (prestasi dalam bidang militer) dan seargenty (jasa-jasa yang bersifat pribadi). ${ }^{14}$ Non-Free Tenure lama-lama dihapuskan, menyusul dihapuskannya kewajibankewajiban feudal dan jasa-jasa. Perkembangan lebih jauh Tenant seolah-olah sebagai pemilik, kecuali Tenant tidak memiliki keturunan, maka tanah tersebut kembali kepada raja berdasarkan ketentuan Escheat. Keberadaan ini dalam tradisi Civil Law mirip ketentuan tanah terlantar (Bona Vacantia) sebagai:" Vacant goods. escheats to state because no owner property. ${ }^{15}$

Tenant adalah pemegangan (holder) yang

\footnotetext{
Termasuk ke dalam kelompok Common Law Tradition berasal dari Anglo Saxon adalah Inggris, Anglo Amerika, Irlandia, Australia, Selandia Baru, Canada (Kecuali Quebec) dan Amerika Serikat (kecuali Lousiana). Hukum Romawi tidak diterima di kelompok ini, walaupun Inggris pernah dikuasai oleh Kerajaan Romawi. Sebaliknya Amerika Latin tidak pernah dikuasai Kerajaan Romawi namun hukum Romawi diterima di wilayah tersebut. John Henry Merryman, 2007, The Civil Law Tradition 3rd Edition, Stanford University Press, California, hlm. 6-13.

Wilayah Civil Law adalah Eropa Daratan dan Amerika Selatan dan juga meliputi Indonesia berdasarkan tradisi dan sejarah. Landasan bersama kelompok ini adalah diterimanya hukum Romawi, bukan karena wilayah-wilayah tersebut dijajah dan tunduk pada kekuasaan hukum Romawi. Ibidjuga dapt dibaca pada Edgar Bodenheimer, et al., 1980, An Introduction to Anglo American Legal System 2nd Edition, American Series, St Paul Minn, hlm. 32-41.

Edward H. Raburn dan Roberta Rosenthal Knoll, 1992, Fundamental of Real Poerty Law, The Fundamental Press, New York, hlm. 174. Djasadin Saragih, 1995, Perbandingan Ilmu Hukum, Bahan Ajar Program Magister Hukum Program Pasca Sarjana Universitas Airlangga, hlm. 2-6.

Kitab Undang-Undang Hukum Perdata.

Dalam tulisan ini tetap disebut BW dan tidak diterjemahkan sebagai Kitab Undang-Undang Hukum Perdata karena tidak ada Penjelasan Resmi untuk itu.

Djasadin Saragih, Op.cit., hlm. 7

Henry Campbell Black, 1996, Black's Law Dictionary, West Publishng, St. Paul Minn, hlm. 1466.

Djasadin Saraih, Op.cit., hlm. 11-13.

Henry Campbell Black, Op.cit., hlm. 666.

Ibid, hlm. 1469

Ibid., hlm. 177.
} 
mempunyai hak penguasaan atas tanah dan memperoleh perlindungan terhadap pihak ketiga atas gugatan kebendaan yang memperoleh kembali bendanya tersebut (Real Action). ${ }^{16}$ Seseorang yang memiliki seized terhadap sebidang tanah, maka ia dapat mempertahankan haknya sampai ada pihak lain yang dapat membuktikan bahwa haknya lebih kuat. Terhadap pihak ketiga Tenant tidak dapat mendalilkan haknya, sehingga muncul istilah the tenant is seized of the land (seizing), yaitu tanah dalam keadaan disita yang mirip dengan kedudukan berkuasa (Bezit) dalam tradisi Civil Law. ${ }^{17}$

Seizing dalam perkembangan lebih lanjut, merupakan hak yang dapat dialihkan dan diwariskan. Faktor waktu yang akan digunakan sebagai pembatas hubungan dengan seizing. Bila dibandingkan dengan tradisiCivil Law, digunakan konstruksi Hak Menikmati Hasil (Frucht Gebruik). ${ }^{18}$ Tenant berhak untuk menikmati dengan menolong dirinya sendiri berkenaan dengan faktor waktu yang menjadi faktor juridis, contoh, seorang diakui sebagai pemegang selama hidup $\mathrm{x}$ demikian pula $\mathrm{y}$ yang berhak kemudian - seized dalam periode $\mathrm{x}$ dan y itulah yang dinamakan Estate. Ada Estate dalam Common Law yang seperti hak milik (eigendom) dalam Civil Law, namun dengan struktur yang berbeda. ${ }^{19}$ Estate didefinisikan sebagai: "Estate and heirs is not equivalent terms. Estate is the degree, quantity, nature and extent of interests which person has right in real or personal property." ${ }^{20}$

Estate adalah pengertian juridis yang menunjukkan adanya hubungan antara seseorang dengan benda tetap. Estate merupakan hak menguasai benda tetap. Artinya I own an estate in land'. Inilah yang dimaksud dengan istilah 'ownership' atas benda tetap. ${ }^{21}$ Apabila kita bandingkan dengan tradisi Civil Law, hak tersebut mirip dengan hak-hak bendaan yang terkait dengan hak milik yang melekat pada bendanya (droit de suite) dan hak untuk diutamakan (droit de preference). ${ }^{22}$ Kedudukan estate diunggulkan estate yang lebih tua daripada estate yang lebih muda. Selanjutnya Estate dibedakan menjadi free hold estate dan non free hold estate. Free hold estate sendiri terdiri atas: (a) Estate in fee simple absolute; (b) Estate in fee simple conditional. ${ }^{23}$

Estate in fee simple absolute ${ }^{24}$ mempunyai peranan yang sangat besar dalam hukum waris karena seized dapat dipindahtangankan dan dapat dimasukkan dalam wasiat. Estate in fee simple ini jangka waktunya tanpa batas merupakan absolute owner. Jadi ini dapat dipadankan dengan hak milik (eigendom) dalam Civil Law. Sementara, kalau Estate in fee simple conditional ${ }^{25}$ itu jatuh pada yang berhak semula jika dipenuhi syarat tertentu yang tidak berlaku surut variannyanya terdiri dari: Pertama, Estate in fee tail ${ }^{26}$, Suatu estate yang jangka waktunya terbatas karena kemungkinan untuk mewariskannya lebih terbatas, sebab pewarisan hanya dapat terjadi pada turunan atau kelompok-kelompok tertentu dari tururnan tersebut. Jadi pada mereka seolah-olah ada harapan memperoleh sesuatu dari para ahli waris tertentu. Ini mengakibatkan pemegang estate in fee tail tidak dapat mengalihkan estate-nya karena kalau dialihkan akan merugikan ahli waris.

\footnotetext{
Djasadin Saragih, Op.cit., hlm. 18-21. Juga pada Edward H. Radburn dan Roberta Rosenthal Knull, Op. cit., hlm.177-178.

Ibid. hlm. 22-24. Juga pada Rahmi Jened, "Perbandingan Hukum Benda Antara Civil Law dan Common Law", Yuridika, Volume 3 Nomor X, Januari - Februari, 1995 (selanjutnya disebut Rahmi Jened II), hlm.1-5. M. Isnaeni, 2018, Hukum Benda dalam Burgerlijke Wetboek, Revka Petra Media, Surabaya, (HM. Isnaeni I), hlm. 43-47.

Djasadin Saragih, Op.cit., hlm. 25-26.

9 Djasadin Saragih, Loc.cit., Juga pada Rahmi Jened, Perbandingan Hukum Benda Antara Civil Law dan Common Law", Makalah Tugas Mata Kuliah Djasadin, Program Magister Hukum Program Pasca Sarjana Universitas Airlangga, 1995. Lihat juga Edward H. Radburn dan Roberta Rosenthal Knull, Op.cit., hlm. 177-179.

Henry Campbell Black, Black's Law Dictionary, West Publishng, St. Paul Minn, 1996, hlm. 547-549.

Edward H. Radburn dan Roberta Rosenthal Knull, Op.cit, hlm. 181-182.

Djasadin Saragih, Op. cit., hlm. 30-31. H. M. Isnaeni. I, Op.cit., hlm. 15-1.

Henry Campbell Black, Op. Cit., hlm. 547. Juga pada Edward H. Radburn dan Roberta Rosenthal Knull, Op.cit., hlm. $172-175$.

Ibid., hlm. 547 Juga pada Edward H. Radburn dan Roberta Rosenthal Knull, Op.cit., hlm. 173.

Ibid., hlm. 550

Ibid., hlm. 549.
} 
Kedua, Estate for life (life estate) ${ }^{27}$, Estate ini akan berakhir pada saat yang berhak meninggal dunia. Hal ini padanannya dengan Hak Pakai (Gebruik Rechten) $^{28}$ dalam Civil Law. Estate for life akan berakhir dengan dipenuhinya syarat tertentu (kembali kepada pemilik semula). Ketiga, Reversionary estate ${ }^{29}$, Estate yang diserahkan kepada pihak lain selama hidupnya. Jadi ada suatu seized yang berakhir dengan meninggalnya pihak lain tersebut. Terkahir adalah Remainder Estate ${ }^{30}$, Suatu estate yang diberikan sesuai dengan kemauan/ keinginan dari pemegang estate. Padanannya hibah (Schenking) dalam Civil Law.

Non-Fee Hold Estate tidak termasuk transaksi komersial, tetapi hanya terjadi dalam lingkungan keluarga. Hal terpenting dalam non free hold estate adalah estate for years (lease hold estate) adalah suatu estate yang berlaku dalam sejumlah tahun tertentu, sedangkan dalam free hold estate jangka waktunya tidak ditentukan yang juga masuk kategori hukum perjanjian. Jadi non free hold estate muncul kemudian daripada free hold estate. ${ }^{31}$ Hak ini mirip dengan Hak Guna Usaha (Erfpacht) dalam Civil Law. ${ }^{32}$

Orang yang bersangkutan hanya mempunyai possession (suatu bentuk bezit yang berkenaan dengan benda bergerak) dalam estate for years ini, karena orang yang bersangkutan tidak dapat menggunakan gugatan atas benda tetap (Real Action) tapi hanya gugatan atas benda bergerak (personal action). Hal tersebut membawa konsekuensi bahwa estate for years tidak selalu benda tetap, tetapi menempati posisi antara benda tetap (Real Property) dan benda bergerak (Personal Property). Dapat dikatakan sebagai Chattels Real dalam hubungan ini, yang lambat laun tidak lagi dibedakan dengan Real Property dan merupakan bagian dari Real Property. ${ }^{33}$ Tradisi Common Law System menempatkan secara mandiri estate for years yang berkenaan dengan sewa benda tetap, diatur dalam The Law of Land and Tenant. Letaknya dalam Real Property law yang diliputi ketentuan hukum yang bersifat memaksa. ${ }^{34}$

Sejumlah estate mengalami perluasan dibawah pengadilan Equity, muncul kategori baru estate yang dinamakan Executory estate yang berlaku dengan bantuan faktor waktu, khusus kadaluarsa penghapusan (extinctive), baik dengan pereseran (shifting) ataupun penangguhan (springing). Selain itu, dalam tradisi Common Law, pengaruh peradilan Equity diawali dengan pengenaan use yang merupakan suatu hubungan hukum yang timbul bila seseorang yang mempunyai estate mengalihkan kepada orang lain dengan perintah agar orang lain mengolah estate tersebut demi kepentingan pihak pertama Land Lord). Ini mirip dengan Fiducia dalam sistem Civil Law. ${ }^{35}$ Oleh pengadilan Common Law" Equity", use ini dikembangkan menjadi Trust, sehingga muncul Equitable Interest, dan lain-lain. ${ }^{36}$

Tradisi Common Law mengatur mengenai jaminan atas benda tetap dengan mortgage Estate yang diciptakan sebagai jaminan demi kepentingan kreditur. Hal yang sama bisa dilakukan terhadap benda yang sama pula (subsequent mortgage), misalnya mortgage I berlangsung 9 tahun +2 hari; mortgage II berlangsung 9 tahun +3 hari dan seterusnya. Apabila mortgage I sudah dilunasi, maka mortgage II akan menggantikan posisinya. Mortgage diartikan sebagai:" an interest in land created by a written instrument in proving security for the performance of a duty or the Pyment by a

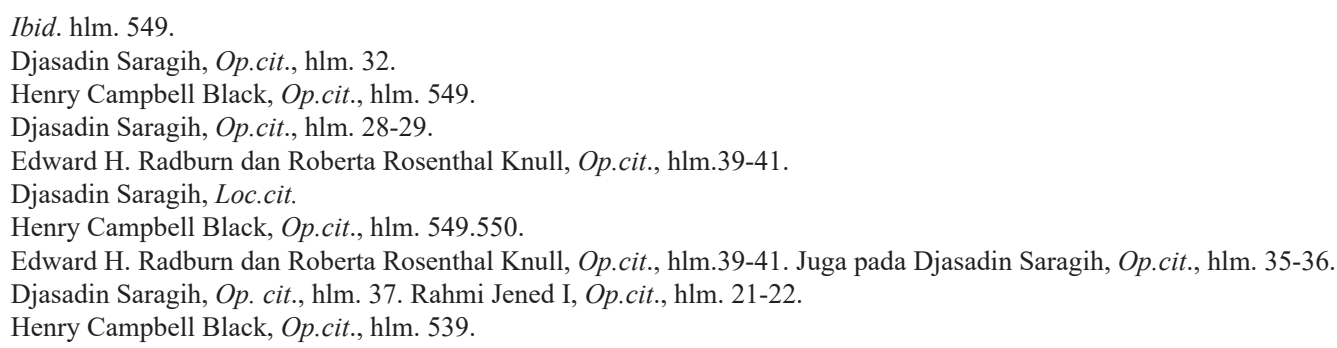


debtor. ${ }^{37}$ Mortgage ini mirip dengan ketentuan Hipotik dalam Civil Law, dimana hak-hak yang diperoleh dari penyerahan untuk dijadikan jaminan (overdracht tot zakerheid atau eigendom tot zakerheid). ${ }^{38}$

\section{Sekuritas SMF: Jual Putus Penjualan Kredit dan Hak Tanggungannya}

Mekanisme sekuritisasi SMF dapat digambarkan dengan tahapan sebagai berikut: (1) Bank memproduksi KPR atau telah memiliki KPR eksisting; (2) SMF membeli atas perkumpulan hak tagih KPR (pool KPR) dari bank untuk jangka waktu tenor yang diperjanjikan Diana pada tanggal jauh tempo bank wajib membeli kembali pool KPR tersebut sebesar nilai sisa pokoknya atau bank dapat memperpanjang tenor apabila disepakati; (3) Walaupun transaksi pembelian kembali (Repurchase Agreement/ REPO) KPR secara legal menggunakan perjanjian notaril jual beli (Cessie) karena adanya kewajiban bank untuk membeli kembali pool KPR tersebut seluruhnya sehingga tidak true sale pada akhir tenor, maka secara akuntansi tetap diperlakukan sebagai utang piutang (on balance sheet) dengan program REPO KPR asset bank tidak berkurang justru bertambah, sesuai untuk bank yang ingin memperbesar asetnya (Penjelasan Pembukaan REPO KPR); (4) Bank melakukan pembayaran kepda SMF sesuai jadwal angsuran yang disepakati sampai dengan jatuh tempo REPO KPR; (5) Pendanaan SMF untuk pembiayaan RePO KPR menggunakan dana dari penerbitan obligasi dengan agunan berupa kumpulan hak tagih pool KPR dari transaksi RePO KPR tersebut; dan (6) Bank membeli kembali nilai sisa pokok pool KPR pada saat jatuh tempo REPO KPR. ${ }^{39}$

Mekanisme tersebut di atas minimal melibatkan 4 (empat) pihak yaitu: (1) Bank
KPR sebagai penjual hak tagih atau mortgagor (originator); (2) Debitur KPR; (3) PT SMF sebagai pemberi pinjaman atas hak tagih atau mortgage lender (Special Purpose Vehicle/ SPV); dan (4) Pemodal (Investor). Dalam hubungan Hukum antara Bank Pemberi KPR dengan Debitor KPR terdapat 4 (empat) tahapan penting yaitu: (1) Akta pemberian kredit; (2) Untuk menjamin perjanjian utang piutang yang timbul dari perjanjian kredit tersebut, Bank KPR meminta agunan dari pihak Debitor KPR; (3) Surat Kuasa Memasang Hak Tanggungan (SKMHT); dan (4) Akta Pembebanan Memasang Hak Tanggungan (APHT) ${ }^{40}$

Perjanjian kredit Pemilikan Rumah yang terjadi antara Bank KPR dengan debitor KPR merupakan perjanjian utang piutang. Perjanjian utang piutang ini menurut Marhainis Abdul Hay merupakan perjanjian pinjam meminjam yang diatur dalam Pasal 1754 sampai dengan 1769 Buku III Bab XIII BW..$^{41}$ Pasal 1754 KUH Perdata menetapkan bahwa "Pinjam meminjam ialah persetujuan dengan mana pihak yang satu memberikan kepada pihak lain suatu jumlah tertentu barang yang menghabis karena pemakaian, dengan syarat bahwa pihak yang belakangan ini akan mengembalikan sejumlah yang sama dari macam dan keadaan yang sama pula”.

Sedangkan Mariam Darus Badrulzaman secara berbeda menyatakan bahwa perjanjian kredit tidak identik dengan perjanjian pinjam meminjam karena perbedaan unsur-unsurnya. ${ }^{42}$ Perjanjian pinjam meminjam (Pasal 1754 BW) adalah perjanjian riil, sedangkan perjanjian kredit merupakan perjanjian konsensuil dan merupakan perikatan bersyarat dengan syarat-syarat tangguh sebagaimana dimaksud Pasal 1253 juncto Pasal 1263 BW di bawah ini:

\footnotetext{
Ibid., hlm. 1009.

Fabozzi, Frank J., et al., 2008, “Introduction to Mortgage”, Probus Publishing, Chicago, hlm. 167-171. M. Isnaeni, 2018, Lembaga Jaminan kebendaan dalam BW: Gadai dan Hipotik, Riveka Petra Media, (H. M. Isnaeni II), hlm. 129-130.

Direktur Umum PT SMF, Op.cit., hlm. 16.

40 Diolah kembali dari Rahmi Jened, 2012, dkk, Aspek Yuridis Secondary Mortgage Facility Dalam Pembiayaan Perumahan di Indonesia, Laporan Penelitian Dosen muda DP3 M Ditjen DiktiNo. 023/ LIT/ BPPK-SDM/IV/ (Rahmi Jened III).

Marhainis Abdul Hay, 1985, Perjanjian Kredit, Alumni, Bandung, hlm. 15.

Mariam Darus Badrulzaman, 1993, Aspek Hukum Perjanjian Kredit Bank, Citra Adtya Bakti, Bandung, hlm. 34.
} 
Pasal 1253 BW

Suatu perikatan adalah bersyarat manakala ia digantungkan pada suatu peristiwa yang masih akan ada dan yang masih belum tentu akan terjadi, baik secara menangguhkan perikatan hingga terjadinya peristiwa semacam itu, maupun secara membatalkan perikatan menurut terjadi atau tidak terjadinya peristiwa tersebut.

\section{Pasal 1263 BW}

Suatu perikatan dengan suatu syarat tangguh adalah suatu perikatan yang tergantung pada suatu peristiwa yang masih akan datang dan yang masih belum tentu akan terjadi atau yang tergantung pada suatu hal yang sudah terjadi, tetapi tidak diketahui oleh kedua belah pihak.

Sebenarnya dalam Undang-Undang Nomor 7 Tahun 1992 juncto Undang-Undang Nomor 10 Tahun 1998 tentang Perbankan, istilah "Jaminan pemberian kredit" diberi arti "keyakinan bank atas kesanggupan debitor untuk melunasi kredit sesuai dengan yang diperjanjikan". Hal ini terkait dengan Asas jaminan umum (algemeen beslag) ${ }^{43}$ yang diatur dalam Pasal 1331 dan 1132 BW sebagai berikut:

\section{Pasal 1131 BW}

Segala kekayaan debitor baik yang bergerak maupun tidak bergerak, baik yang sudah ada maupun yang baru akan ada dikemudian hari menjadi tanggungan bagi segala perikatannya.

\section{Pasal 1132 BW}

Kebendaan itu menjadi jaminan bersamasama bagi semua orang yang mengutangkan padanya; pendapatan penjualan benda-benda itu dibagi-bagi menurut keseimbangan, yaitu menurut besar kecilnya piutang masingmasing, kecuali apabila diantara para berpiutang itu ada alasan yang sah untuk didahulukan.

Lebih lanjut Pasal 1133 BW menetapkan bahwa:" di antara orang-orang berpiutang terbit dari hak istimewa, dari gadai dan dari hipotik (catatan peneliti hipotik sekarang telah diganti dengan hak tanggungan)". Pasal-pasal ini mengatur asas jaminan umum, sehingga pada dasarnya tidak ada kredit yang tidak dijamin. ${ }^{44}$ Bank KPR dalam perjanjian kredit ini berposisi sebagai kreditor yang diutamakan (preferen) karena memiliki agunan yang dijamin dengan hak tanggungan atas tanah dan bangunan KPR.

Sebenarnya antara Debitor KPR dengan pihak Pengembang (developer) terjadi perjanjian jual beli, walaupun untuk pembayarannya berdasarkan outstanding Bank KPR yang akan melakukan pembayaran, Perjanjian jual beli diatur dalam Pasal 1457 sampai dengan 1540 BW Perdata. Pasal 1457 BW menetapkan bahwa: "Jual beli adalah suatu persetujuan dengan mana pihak yang satu mengikatkan diri untuk menyerahkan suatu kebendaan dan pihak yang lain untuk membayar harga yang telah diperjanjikan". Lebih lanjut Pasal 1458 BW menetapkan bahwa: "Jual beli dianggap telah terjadi seketika tercapainya kata sepakat, meskipun kebendaan itu belum diserahkan atau harganya belum dibayar".

Selanjutnya Pasal 1459 BW menetapkan bahwa: "Hak milik atas barang yang dijual tidaklah berpindah, selama penyerahan(levering)-nya belum dilakukan menurut Pasal 612, 613 dan 616 BW". Khusus untuk barang tidak bergerak, hak milik baru berpindah setelah dibuat Akta oleh Pejabat Pembuat Akta Tanah yang dapat Notaris PPAT dan/atau Kepala Kecamatan setempat kemudian dilakukan Balik Nama dan pendaftaran perolehan hak atas tanah tersebut kepada Dinas Pertanahan atau Badan Peratanahan Nasional (BPN).

Hubungan Hukum Antara Bank Pemberi KPR selaku morgagor (Originator) dengan Perusahaan SMF selaku Mortgage Lender (Special Purposes Vehicle-SPV) merupakan pembiayaan dalam bentuk perjanjian Pembelian kembali hak tagih (Repurchase agreement) Kredit Pemilikan

43 H. M Isnaeni, 2018, Pengantar Hukum Jaminan Kebendaan, Riveka Petra Media, Surabaya, (H. MIsnaeni III), hlm. 97-98.

44 Remy Syahdeini, "Peranan Jaminan dan Agunan Kredit Menurut UU No. 7/1992 “, Seminar Eksistensi Agunan dan Permasalahannya dalam Perbankan, FH Universitas Surabaya, 1993, hlm. 20-22. 
Rumah (REPO KPR) berdasarkan Akta notariil Jual Putus (True Sale). Berdasarkan Pasal 1 Angka 15 Peraturan Presiden Nomor 1 Tahun 2008 ditetapkan bahwa Perusahaan Special Purposes Vehicle (SPV) adalah: "Perseroan Terbatas yang ditunjuk oleh lembaga keuangan yang khusus didirikan untuk membeli asset keuangan dan menerbitkan Efek Beragun Aset (EBA)". Dengan demikian, SPV adalah perusahaan yang menerima jaminan kedua atau membeli piutang atau tagihan KPR dari Bank $\mathrm{KPR}^{45}$

Apabila kualitas dan atau jumlah tagihan atas kredit pemilikan rumah dan hak tanggungan sebagaimana dimaksud dinilai tidak mencukupi, maka Bank yang memberikan kredit pemilikan rumah( Bank KPR) dapat menggunakan harta lain yang terdiri dari harta tetap atau harta bergerak serta surat berharga yang diperdagangkan di bursa efek di Indonesia sebagai tambahan jaminan dengan Jumlah harta lain yang dapat dijaminkan, ditetapkan setinggi-tingginya sebesar $30 \%$ (tiga puluh per seratus) dari jumlah total jaminan yang diperlukan. Mengingat pembiayaan dari SMF memiliki objek agunan (collateral) tagihan atas KPR tersebut dan Hak Tanggungan atas rumah dan tanah" terkait dengan ketentuan Pasal 613 BW yang menentukan bahwa, penyerahan akan piutang-piutang atas nama dan kebendaan tidak bertubuh lainnya dilakukan dengan membuat suatu akta optentik atau akta di bawah tangan dengan mana hak-hak atas kebendaan itu dilimpahkan kepada orang lain. Penyerahan yang demikian bagi siberhutang tiada akibatnya, melainkan setelah penyerahan itu diberitahukan kepadanya atau secara tertulis disetujui atau diakuinya. Penyerahan tiap-tiap piutang surat bawa dilakukan dengan penyeralian surat itu, penyerahan tiap piutang karena atas unjuk dilakukan dengan penyerahan surat disertai dengan endosemen.
Ketentuan di atas terkait dengan 2 (dua) hal yakni, Pertama, Hubungan antara Cedent (kreditor semula) dengan Cessionaris (kreditor baru) yang berupa pengalihan tagihan dapat terlaksana tanpa bantuan Cessus (debitor lama); Kedua, Hubungan antara Cessionaris (kreditor baru) dan Cessus (debitor lama) dalam arti agar Cessie bisa berlaku terhadap Cessus (debitor lama), maka perlu pemberitahuan (betekening) ${ }^{46}$ atau pengakuan secara tertulis dari Cessus (debitor lama), yang menyetujui pengoperan hak tagih tersebut. ${ }^{47}$

Praktik SMF, didalamnya terdapat pengalihan piutang dari Bank KPR selaku kreditor semula (Cedent) kepada Perusahaan SMF (SPV) selaku kreditor baru (Cessionaris) tidak diberitahukan (betekening) kepada debitor KPR (Cessus). Pengalihannya tidak dalam arti sebenarnya karena debitor KPR tidak tahu dan ini akan membawa konsekuensi Perusahaan SMF (SPV) tidak dapat menagih piutang pada Debitor KPR. Sebaliknya ini akan melemahkan posisi debitor KPR karena ada potensi Debitor KPR tidak memperoleh kembali Sertifikat Hak atas Tanah ketika yang bersangkutan melunasi utang KPRnya. ${ }^{48}$ Oleh karena itu menurut SK Menkeu No. 132/KMK.014/1988 sebagai aturan lama dinyatakan dengan tegas bahwa kumpulan ( $p o o l$ ) hak tagih dan jaminan Hak Tanggungan tetap dalam penguasaan Bank KPR.

Beralihnya tagihan (piutang) ini mengingat sifatnya sebagai pinjaman, maka kumpulan KPR tetap menjadi aset bank berikut resiko yang melekat pada portofolio tersebut, sehingga penerbitan sekuritasnya tidak bisa secara hukum dikaitkan portofolio KPR yang diberikan oleh Bank KPR Kreditor Asal selaku Mortgage Lenders. Memang kepemilikan tagihan sudah beralih kepada SPV, namun jika Bank KPR melunasi utangnya, maka secara otomatis piutang tersebut beralih kembali

\footnotetext{
45 SMF dilihat dari perbankan dimungkinkan oleh peraturan tentang perbankan, antara lain: tentang penyertaan modal dari bank umum. seperti, modal ventura, perusahaan efek dan LKPP. (Lembaga Kliring Penyelesaian dan Penyimpanan) 2. Penyertaan Modal dan Pemilikan Saham oleh Bank antara lain Penyertaan modal adalah penempatan dana dalam bentuk saham yang dilakukan tidak melalui pasar modal (direct placement).

46 H. M. Isnaeni, 2018, Perjanjian Jua Beli, Riveka Petra Media, Surabaya, (H. M. IsneniIV), hlm. 221.

47 Rahmi Jened II, Op.cit., hlm. 12-14.

48 Rahmi Jened, III, Op.cit., hlm. 28-31.
} 
kepada Bank KPR. Inilah yang bagi sebagian orang dikatakan seperti jaminan fidusia. ${ }^{49}$ Sampai disini bukan berarti proses peralihan itu telah selesai, karena dalam kegiatan $S M F$, proses peralihan hak tanggungan antara debitor, Bank KPR (originator), dan perusahaan SMF (mortgagor) akan terkait dengan Undang-Undang Nomor 4 Tahun 1996 Tentang Hak Tanggungan (UUHT).

Hak Tanggungan atas tanah beserta bendabenda yang berkaitan dengan tanah yang selanjutnya disebut Hak Tanggungan adalah hak jaminan yang dibebankan pada hak atas tanah sebagaimana dimaksud dalam Undang-Undang Nomor 5 Tahun 1960 Tentang Peraturan Dasar Pokok-Pokok Agraria (UUPA), berikut atau tidak berikut benda-benda lain yang merupakan satu kesatuan dengan tanah untuk pelunasan utang tertentu, yang memberikan kedudukan yang diutamakan bagi kreditor tertentu terhadap kreditor-kreditor yang lain (Pasal 1 angka 1 UUHT).

Hak Tanggungan mempunyai sifat tidak dapat dibagi-bagi, kecuali diperjanjikan dalam Akta Pemberian Hak Tanggungan sebagaimana dimaksud dalam (Pasal 1 ayat (2) UUHT). Apabila Hak Tanggungan dibebankan pada beberapa hak atas tanah, dapat diperjanjikan dalam Akta Pemberian Hak Tanggungan yang bersangkutan, bahwa pelunasan utang yang dijaminkan dapat dilakukan dengan cara angsuran yang besarnya sama dengan nilai masing-masing hak atas tanah yang merupakan bagian dari objek Hak Tanggungan yang akan dibebaskan dari Hak Tanggungan tersebut. Dengan demikian Hak Tanggungan itu hanya membebani sisa objek Hak Tanggungan untuk menjamin sisa utang yang belum dilunasi (Pasal 2 UUHT).

Hak Tanggungan dapat diberikan untuk suatu utang yang berasal dari suatu hubungan hukum atau untuk satu utang atau lebih yang berasal dari beberapa hubungan hukum (Pasal 3 ayat (2) UUHT). Seringkali terjadi Debitor berutang lebih dari satu Kreditor, masing- masing didasarkan pada perjanjian utang piutang yang berlainan, misalnya kreditor adalah suatu bank dan suatu badan afiliasi bank yang bersangkutan. Piutang para kreditor tersebut dijamin dengan satu Hak Tanggungan kepada semua kreditor dengan satu akta pemberian Hak Tanggungan yang dibebankan atas tanah yang sama.

Suatu objek Hak Tanggungan dapat dibebani dengan lebih dari satu Hak Tanggungan guna menjamin pelunasan lebih dari satu utang (Pasal 5 ayat (1) UUHT). Apabila suatu objek Hak Tanggungan dibebani dengan lebih dari satu Hak Tanggungan, maka peringkat masing-masing Hak Tanggungan ditentukan menurut tanggal pendaftarannya pada Kantor Pertanahan (Pasal 5 ayat (2) UUHT). Peringkat Hak Tanggungan yang didaftar pada tanggal yang sama ditentukan menurut tanggal pembuatan Akta Pemberian Hak Tanggungan yang bersangkutan (Pasal 5 ayat (3) UUHT).

Beberapa ketentuan tersebut menunjukkan peringkat posisi para kreditur, kreditur pertama lebih kuat posisinya daripada kreditur selanjutnya. Namun dalam SMF yang terjadi adalah sebaliknya karena yang memindah tangankan bukan debitornya, melainkan kreditornya. Semula kreditornya adalah Bank KPR berpindah kepada perusahaan SMF $(S P V)$. Apabila Debitor cidera janji, maka pemegang Hak Tanggungan pertama mempunyai hak untuk menjual objek Hak Tanggungan atas kekuasaan sendiri (berposisi sebagai kreditur preferent) melalui pelelangan umum serta mengambil pelunasan piutangnya melalui hasil penjualan tersebut (Pasal 6 UUHT). Hak Tanggungan tetap mengikuti objeknya dalam tangan siapapun objek tersebut berada (Pasal 7 UUHT). Sifat ini merupakan salah satu jaminan khusus bagi kepentingan Pemegang Hak Tanggungan (kreditor). Walaupun objek Hak Tanggungan sudah dipindah tangankan oleh debitornya menjadi milik pihak lain, namun kreditor masih tetap dapat menggunakan haknya melalui

49 Ibid. Fidusia adalah pengalihan hak kepemilikan suatu benda atas dasar kepercayaan dengan ketentuan baliwa benda yang kepemilikannva dialihkan tersebut tetap dalam penguasaan pemilik benda Pasal 1 Angka 1 UU No.42/1999 Tentang Jaminan Fidusia. 
eksekusi, jika debitor cedera janji.

Pasal 16 Ayat (1) UUHT menentukan bahwa " jika terjadi peralihan piutang dengan cara cessie, subrogasi, pewarisan, atau sebab-sebab lain seperti merger, maka hak tanggungan tersebut ikut juga beralih "demi hukum" kepada kreditur yang baru". Kemudian, Pasal 16 Ayat (3) UUHT menetapkan bahwa, Kantor Pertanahan dalam hal ini bertugas untuk mencatat peralihan hak tanggungan tersebut dalam: (a) Buku tanah hak tanggungan; (b) Buku hak atas tanah yang menjadi objek hak tanggungan; (c) Sertifikat hak tanggungan; dan (d) Sertifikat hak atas tanah yang menjadi objek hak tanggungan. UUHT mensyaratkan bahwa peralihan hak tanggungan tersebut harus memenuhi syarat administratif berupa pendaftaran oleh kreditur yang baru kepada kantor pertanahan.

Terlihat bahwa dalam proses cessie Hak Tanggungan dari pihak Bank KPR kepada Perusahaan SMF tidak adanya pemberitahuan (betekening) kepada pihak debitor, sehingga ada atau tidaknya pendaftaran ulang atas peralihan Hak Tanggungan tersebut dibutuhkan kewenangan Badan Pertanahan (BPN) untuk mengadopsi lembaga $S M F$ ini. Selain itu perlu diperhatikan ketentuan Peraturan Menteri Agraria/Kepala Badan Pertanahan Nasional No. 4 Tahun 1996 Tanggal 8 Mei 1998 Tentang Penetapan Batas Waktu Penggunaan Surat Kuasa Membebankan Hak Tanggungan (SKMHT) Untuk Menjamin Pelunasan Kredit-Kredit Tertentu. Hal ini terkait dengan asas Spesialitas dan Publisitas dalam jaminan hak atas tanah..$^{50}$ Hak Tanggungan hapus karena hal-hal sebagai berikut: ${ }^{51}$

a) hapusnya utang yang dijamin dengan Hak Tanggungan, mengingat hak tanggungan bersifat accesoir terhadap perjanjian utang piutang sebagaiperjanjian pokoknya;

b) Dilepaskannya Hak Tanggungan oleh Pemegang Hak Tanggungan; c) Pembersihan Hak Tanggungan berdasarkan Penetapan Peringkat olehKetua Pengadilan Negeri;

d) Hapusnya Hak atas Tanah yang dibebani Hak Tanggungan, walau hal ini tidak menghapuskan utang.

Hubungan hukum antara Perusahaan SMF (SPV) dengan Investor adalah dalam proses Sekuritisasi Perusahaan SMF (SPV) memperoleh pendanaan dengan cara rnenerbitkan Efek Beragun Aset (EBA). Pengertian EBA sesuai Pasal 1 Angka 5 Peraturan Presiden Nomor 1 Tahun 2008 Tentang Peraturan Presiden Nomor 19 Tahun 2005 tentang Pembiayaan Sekunder Perumahan (Perpres 1/2008) adalah:" surat berharga yang dapat berupa surat utang atau Surat Partisipasi yang diterbitkan oleh Penerbit yang pembayarannya terutama bersumber dari Kumpulan Piutang. Ada 3 (tiga) prinsip dasar transaksi sekuritisasi yaitu: (a) Jual putus (true sale); (b) Penjauhan dari kebangkrutan (bankruptcy remoteness); dan (c) Kesempurnaan kepentingan Keamanan (Perfection of security interest). ${ }^{52}$

Definisi "Surat Partisipasi" adalah" bukti kepemilikan secara proporsional atau kumpulan piutang yang dimiliki bersama oleh sejumlah pemodal yang diterbitkan oleh penerbit". Surat partisipasi dalam bentuk surat saham yang memberikan manfaat bagi pemegang saham antara lain: (a) Memberikan kedudukan hukum sebagai pemegang saham; (b) Hak suara berdasarkan prinsip "one share one vote"; (c) Keuntungan hasil usaha (Deviden); (d) Selisih harga saham (Capital gain); (e) Bertanggung gugat terbatas (limited liability) saham yang dimilikinya; dan lain -lain. ${ }^{53}$

Sementara yang dimaksud dengan "Surat utang" menurut Pasal 1 angka 17 Perpres No. 1/2008 adalah:" bukti yang dikeluarkan oleh penerbit yang memberikan hak kepada pemegangnya untuk memperoleh pembayaran sebagai pemodal". Surat

H. M. Isnaeni I, Op.cit., hlm. 141-145.

51 H. M Isnaeni, 2001, Perjanjian Kredit dan /jjaminan, Bahan Ajar Perkuliahan Perjanjian Kredit dan Jaminan, Program Doktor Progrm Pascasarjana Universitas Arlangga Surabaya, hlm. 12-13.

52 David Suprapto, Aspek Hukum Sekuritisasi, Pelatihan Hukum Pembiayaan Perumahan, Kerjasama PT (Persero) SMF dengan Program Kenotariatan Fakultas Hukum Universitas Airlangga, Surabaya, 6-7 Desember 2014, hlm. 12.

53 Rudhi Prasetya, 2001, Hukum Perseroan dalam Globalisasi Ekonomi, Program Doktor Program Pasca Sarjana, Universitas Airlangga, Surabaya, hlm. 6-7. 
utang atau surat obligasi memberikan manfaat bagi pemegangnya: (a) Kedudukan sebagai kreditor; (b) Berhak atas pelunasan utang pokok sesuai jadwal tenor yang diperjanjikan; (c) Bunga-bunga pinjaman; dan (d) menjual obligasi (corporate bond) kepada investor.

Praktik REPO KPR dan sekuritisasi oleh PT SMF didalamnya dapat terlihat pengumpulan dana investor dalam bentuk penjualan obligasi yang sering disebut Mortgage Securities dan investor berposisi sebagai kreditor. ${ }^{54}$ Definisi Investor atau Pemodal menurut Pasal 1 angka 12 Perpres No. 1/2008 adalah:" orang atau badan pemegang Efek Beragun Aset (EBA)". Lazimnya pemodal (investor) adalah: (a) Pemerintah; (b) Lembaga Internasional; (c) Dana Pensiun; dan (d) Perusahaan Asuransi. PT SMF akan bertindak selaku emiten yang bersangkutan tunduk pada undang-Undang Nomor 8 Tahun 1995 tentang Pasar Modal (UUPM), dalam rangka sekuritisasi REPO KPR. Apabila SMF mengeluarkan obligasi, maka diperhatikan pihak-pihak yang terkait antara lain: ${ }^{55}$

a) Underwriter dapat memiliki hubungan afiliasi dengan emiten (SMF/ SPV) sepanjang diungkapkan secara tegas;

b) Wali Amanat dapat dilaksanakan oleh Bank Umum atau pihak lain yang ditetapkan oleh Peraturan Pemerintah;

c) Wali Amanat dilarang mempunyai hubungan afiliasi dengan emiten, kecuali karena penyertaan modal pemerintah;

d) Wali Amanat dilarang mempunyai hubungan kredit dengan emiten dalam jumlah sesuai dengan ketentuan Bapepam yang dapat mengakibatkan benturan kepentingan antara Wali Amanat sebagai Kreditur dan wakil pemegang efek yang bersifat hutang;

e) Wali Amanat dilarang sebagai penanggung emisi efek yang bersifat hutang yang sama untuk menghindari benturan kepentingan.

Sebaliknya, jika SMF mencatatkan obligasinya di Bursa Efek, maka perlu diperhatikan: (a) Pernyataan pendaftaran telah efektif dari Bapepam; (b) Laporan Keuangan perusahaan diperiksa oleh akuntan yang terdaftar di Bapepam dengan opini wajar tanpa syarat untuk tahun buku terakhir; (c) Nilai nominal obligasi yang dicatat minimum Rp.25.000.000.000; (d) Rentang waktu efektif pernyataan pendaftaran dan pencatatan tidak lebih dari 6 bulan serta jatuh tempo obligasi minimum 4 tahun; (e) Perusahaan telah beroperasi sekurang-kurangnya 3 tahun; (f) Dalam 2 tahun buku terakhir perusahaan telah mempunyai laba operasional; (g) Komisaris dan direksi memiliki reputasi yang baik. Persyaratan-persyaratan tersebut di atas tidak berlaku bagi Obligasi Pemerintah, Obligasi Pemerintali Daerah dan Obligasi lain yang dicatatkan atas permintaan Menteri Keuangan.

Berdasarkan pembahasan tersebut di atas, maka menurut hemat penulis peralihan piutang dari Bank KPR kepada perusahaan SMF adalah Cessie sebagai perbuatan hukum mengalihkan piutang oleh Bank KPR selaku mortgagor atau Originator kepada pihak lain PT SMF selaku mortgage lender atau $S P V$ yang bersifat khusus karena tidak adanya notifikasi (betekening) kepada debitor KPR.

Berpegang pada pernyataan Direktur PT Persero $\mathrm{SMF}^{56}$ yang menyatakan bahwa program Program REPO KPR memberikan hak bagi bank KPR untuk membeli kembali hak tagih pool KPR sesuai jangka waktu REPO KPR, maka lembaga hukum SMF ini dapat dikatagorikan sebagai jual beli dengan hak membeli kembali sebagaimana diatur dalam Pasal 1547 juncto Pasal 1520 BW. H.M. Isnaeni pakar Hukum Perjanjian Kredit dan Jaminan menyatakan bahwa:

\footnotetext{
54 Hal ini agak berbeda dengan praktik yang diatur ketentuan lama SK Menkeu RI No. 132/KMK.014/1998 yang melakukan sekritisasi dengan instrument EBA surat partisipasi dan surat saham, sehingga investor dapat memilih posisi sebagai kreditor (creditor) atau sebagai pemegang saham (share holders).

55 Tanpa nama, "Legal Framework of The Secondary Mortgage Facility", Seminar, Seminat Perusahaan Fasilitas Sekunder Perumahan Sebagai Solusi Pembiayaan Jangka Panjang sektor Perumahan, Jakarta, November, 1998, hlm. Tanpa halaman. Dapat juga dilihat di Rahmi Jened, "Teori Hukum SMF”, Pelatihan, Pelatihan SMF Kerjasama PT Sarana Multifinasnsial (Persero) dengan Program Magister Kenotariatan Fakultas Hukum Universitas Airlangga, Surabaya 6-7 Desember 2014, hlm. 3-6.

56 Direktur PT SMF, Loc.cit.
} 
Perjanjian jual Beli dengn hak Membeli Kembali dengan Hak Membeli Kembali pernah dipergunakan sebagai kedok oleh para rentenir untuk menyembunyikan kegiatannya yang menyalurkan pinjaman ... juga nyaris dipergunakan sebagai kebijakan untuk mengemas proses sekuritisasi piutang istimewa milik bank penyalur KPR... namun ditengarai banyak mengandung kelemahan dan resiko[... $]^{57}$

Mengingat jangka waktu (tenor) REPO KPR bisa lebih dari 5 (lima) tahun. Padahal menurut Pasal 1520 dan 1521 BW, jika diperjanjikan jangka waktu hak membeli kembali diperjanjikan lebih daripada 5 (lima) tahun harus dianggap sebagai 5 (lima) tahun. Jangka waktu untuk membeli kembali harus diartikan secara mutlak, bahkan hakimpun tidak diperbolehkan untuk memperpanjangnya. ${ }^{58}$ Lebih menarik hal ini karena menurut Konsultan Hukum Pasar Modal di forum yang sama bahwa SMF merupakan true sale dengan pernyataannya:

\section{merujuk pada "penjualan tagihan/ aset keuangan yang sebenarnya atau sesungguhnya, bukan sekedar pembiayaan. Berdasarkan konsep "true sale", maka hak milik atas tagihan harus beralih kepada pembeli sehingga penjual tidak lagi mengontrol aset tersebut dan tidak memiliki hak atau kewajiban untuk membeli kembali". ${ }^{99}$}

Lebih lanjut David Suprapto menyatakan bahwa persyaratan jual putus adalah: (a) Seluruh manfaat dari asset keuangan telah dialihkan; (b) Resiko kredit dari asset keuangan secara signifikan telah beralih; dan (c) Kreditur asal btidak memiliki pengendalian baik langsung ataupun tidak langsung atas asset keuangan yang dialihkan. ${ }^{60}$

Mengingat dalam Common Law tidak dikenal pembagian hukum benda dan tidak dikenal hak milik atas Tanah dalam arti yang sesungguhnya, maka konsep True sale tidak ada padanannya dalam Civil
Law Tradition. Hal ini mengingat jual beli piutang atau hak tagih tidak cukup dengan penyerahan nyata (feitelik levering), namun juga dengan penyerahan juridis (juridische levering) sesuai sesuai ketentuan Pasal 1477 juncto Pasal 613 BW yaitu dengan cessie. Pasal 1533 BW menegaskan bahwa penjualan piutang meliputi segala sesuatu yang melekat padanya seperti penanggungan hak istimewa dan hipotik. Mengingat piutang KPR adalah piutang atas nama, maka penyerahan nya dengan membuat akta cessie diikuti adanya pemberitahuan (betekening). ${ }^{61}$

Ada kekhususan mengingat dalam Hak Tanggungan yang pertama (primary mortgage), pihak Bank KPR memberikan kredit kepada debitor KPR dan menanggung serta mengelola kredit tersebut (underwrite and service the loan). Dalam hal Hak Tanggungan kedua (pembiayaan SMF) dalam aturan lama masih dimungkinkan varian pembiayaan SMF with recourse dan SMF without recourse. Sedangkan lembaga true sale dalam Common Law hanya menggantikan pembiayaan SMF yang bersifat recourse credit. $^{62}$ Selain itu dinyatakan bahwa kumpulan (pool) sertifikat sebagai agunan (collateral) hak Tanggungan yang pertama (primary mortgage) tetap berada dalam pengelolaan Bank KPR (motgagor). Untuk itu perlu kajian yang mendalam mengenai aturan Jual Beli, hak milik, levering dan resiko yang saat ini diatur dalam ketentuan Pasal 1457, Pasal 1459 BW juncto 612 dan 613 BW serta Pasal 1477 BW dalam merespon perkembangan yang ada.

\section{Eksistensi SMF sebagai Kendaraan untuk Tujuan Khusus (Special Purpose Vehicle/ SPV)}

Pasar modal adalah merupakan alternatif sumber pendanaan yang sangat menjanjikan bagi dunia usaha. Instrumen yang kini semakin marak diperdagangkan di pasar modal adalah obligasi Efek Beragun Aset/EBA (Asset-Backed Securities)

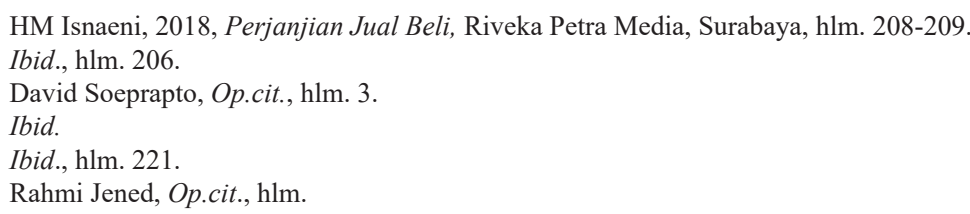


sebagai suatu instrument dalam proses pencarian dana melalui penerbitan efek yang di back up oleh aliran dana yang akan ada di masa depan yang berasal dari kumpulan aset yang menghasilkan revenue terhadap efek yang dapat diperdagangkan. Tujuan sekuritisasi adalah agar suatu perusahaan dapat menambah modalnya dengan cara mengubah asetnya berupa tagihan yang tidak likuid menjadi likuid. PerusahaanSMF dalamhal inimensekuritisasi aset berposisi sebagai Special Purpose Vehicle $(S P V)$ disebut juga Special Purpose Company $(S P C)$ atau Special Purpose Entity (SPE) yang dari berbagai literature merupakan entitas yang menjadi "bankruptcy-remoteness". SPV adalah perusahaan yang didirikan dengan tujuan tertentu atau khusus seperti sekuritisasi aset, mengeluarkan surat hutang, mengakuisisi aset dan lain-lain.

Baik lembaga SPV ataupun fungsinya sebagai bankruptcy-remote entity ${ }^{63}$ merupakan suatu rekayasa keuangan (financial engineering). SPV sebagai instrumen untuk off-balance sheet atas liabilities dan kerugian agar tidak mengotori laporan keuangan sebagai bagian dari risk management. Fungsi "bankruptcy-remote entity" membuat perusahaan SMF terbebas dan tidak terpengaruh oleh kepailitan perusahaan yang mengalihkan aset (bank KPR) selaku kreditur asal (originator), sehingga ini akan menimbulkan perasaan aman ( perfection of security interest) bagi investor REPO KPR. Namun patut diingat hal ini sangat melemahkan posisi debitor KPR dan potensi pengabaian atas prinsip kehati-hatian bank (banking prudential principle) sebagaimana diatur dalam Perturan Bank Indonesia Noor 7/4/PBI/2005 Tentang Prinsip Kehati-hatian dalam Aktivitas Sekuritisasi Aset bagi Bank Umum.

Selain itu. ada Surat Keputusan Menteri Keuangan No. 448/ KMK.0.17/2000 tentang Perusahaan Pembiayaan. Pasal 15 peraturan tersebut didalamnya mensyaratkan, bahwa jumlah maksimal penyertaan modal bagi badan hukum (pemegang saham berbadan hukum) pada suatu perusahaan pembiayaan, adalah sebesar modal sendiri: (1) Bagi pemegang saham yang berbentuk hukum, jumlah penyertaan modal pada perusahaan pembiayaan ditetapkan setinggi-tingginya sebesar modal sendiri dikurangi dengan penyertaan yang dilakukan; (2) Modal sendiri sebagaimana dimaksud dalam ayat (1) untuk yang berbentuk hukum Perseroan Terbatas merupakan penjumlahan dari modal disetor, agio saham, cadangan dan saldo laba, dikurangi penyertaa; dan (3) Modal sendiri sebagaimana dimaksud dalam ayat (1) untuk yang berbentuk hukum Koperasi merupakan penjumlahan dari simpanan pokok, simpanan wajib, hibah, modal penyertaan, dana cadangan dan sisa hasil usaha dikurangi penyertaan.

Berdasarkan aturan tersebut di atas, SPV baik secara kepemilikan penuh (wholly-owned) ataupun pemilikan mayoritas (majority owned) wajib memiliki minimal jumlah modal yang tidak dapat ditarik sebesar penyertaannya pada perusahaan target. ${ }^{64}$

\section{Penutup}

Berdasarkan pembahasan tersebut di atas dapat disimpulkan bahwa ada perbedaan mendasar baik secara filosofis, konseptual, hukum dan aturan antara tradisi Common Law dan Civil Law tentang: Pertama, Hak Milik dan hak atas tanah serta pembebanan jaminan hak atas tanah bahwa pada prinsipnya tidak ada hak milik untuk benda tetap dalam tradisi CommonLaw karena semua benda ada milik Tuhan dan wakil Tuhan di bumi adalah Raja. Sedangkan di tradisi Civil Law ada pembagian hukum benda sebagaimana diatur dalam Buku II BW. Hal ini kemudian diderivasi benda bergerak dan

\footnotetext{
David Suprapto, Loc.cit.

64 Penggunaan SPV di Indonesia telah menimbulkan pro dan kontra sejak adanya privatisasi dan divestasi yang dilakukan Pemerintah atas kepemilikannya di berbagai perusahaan terutama Indosat dan Bank Central Asia (BCA) melalui SPV Indonesian Communication Limited dan Farallon Capital, walaupun yang mengedepan pada saat itu terkait dengan kepemilikan asing dan kembalinya control perusahaan pada pemilik semula. Tanpa nama, "Jangan Sampai Mereka Stop Berkarya", kompas.com, diakses 30 Juli 2014. Gugatan Tri Polyta oleh 97 krediturnya di Pengadilan Negeri Serang. karena sejak awal Juli 2003 Tri Polyta tidak lagi membayar bunga. "Kreditur Asing Sayangkan Gugatan Tri Polyta", hukumonline.com, diakses 30 Juli 2014.
} 
benda tetap tersebut dapat enjadi objek hak milik (Eigendom) Dalam tradisi Common Law, fungsi Real Property Law sebagai hukum yang berhubungan dengan benda tetap bersifat sangat sentral terlebih dikaitkan dengan hukum kontrak yang jika dibandingkan dengan tradisi Civil Law merupakan hak kebendaan yang melekat pada bendanya (droit de suit) dimana pemilik memiliki hak diutamakan (droit e preference). Pembebanan hak estate didasakan pada Mortgage, sedangkan dalam Civil Law didasarkan pada Hipotik sebagai hak-hak yang diperoleh dari penyerahan untuk dijadikan hak milik yang berobjek benda tetap.

Kedua, Sekuritisasi: Jual putus (true sale) penjualan kredit KPR dan hak tanggungannya dalam tradisi Common Law tidak dikenal dalam tradisi Civil Law karena sesuai Pasal 1457, Pasal 1477 juncto Pasal 613 BW, maka lembaga hukum untuk pengalihan piutang adalah cessie yang mewajibkan pemberitahuan (betekening) kepada Debitor KPR, sedangkan adanya REPO KPR dari bank KPR kepada Perusahaan SMF tidak diberitahukan Debitor KPR dengan alasan kumpulan KPR dan Hak Tanggungannya tetap dalam penguasaan Bank KPR selaku originator. Bahkan dalam REPO KPR ada klasula" Jual Beli dengan hak membeli Kembali. Sesuai ketentuan Pasal 1520 dan 1521 BW, maka jangka waktu (tenor) untuk membeli kembali dibatasi untuk 5 (lima) tahun. Di samping itu masih ada kewajiban hukum yang terkait dengan uaspek publisitas dan spesialitas dalam pengalihan piutang KPR dan hak tanggunganya. Ketiga, eksistensi perusahaan kendaraan untuk tujuan khusus (SPV) terkait dengan "rekayasa keuangan (financial engineering)" bertujuan untuk memberikan kesempurnaan kepentingan pengamanan (perfection security interest) bagi investor REPO KPR.

Adapun saran yang dapat diajukan dalam makalah ini adalah: Pertama, Pemerintah Republik Indonesia dalam perannya baik sebagai provider, regulator, entrepreneur ataupun umpire adalah dalam rangka mencapai Tujuan Nasional "Kesejahteraan bagi seluruh Rakyat Indonesia", untuk itu peraturan dan kebijakan yang diambil Pemerintah harus berorentasi untuk perlindungan hukum terhadap rakyat. Kedua, dalam merespon perkembangan aktivitas komersial yang ada, perlu dilakukan penelitian yang mendalam terkait dengan perubahan aturan umum menyangkut jual beli, levering, hak milik dan resiko yang diatur dalam BW agar perubahan dalam rangka adopsi lembaga hukum dari tradisi Common Law tidak terkesan tambal sulam dan dipaksakan. Dalam mengadopsi lembaga hukum yang berasal dari tradisi Common Law System perlu kearifan dan kecermatan yang mendalam agar tidak merusak sendi-sendi hukum Indonesia.

Ketiga, dalam rangka sekuritisasi aset, perlu pengawasan dan monitoring secara terus menerus dari pemerintah agar lembaga SPV tidak dijadikan sebagai sarana penyelundupan hukum. antara lain, SPV yang bermodal seadanya yang dengan itikad buruk (bad faith) bermaksud mengeruk keuntungan tanpa disertai komitmen serius dalam mengelola perusahaan target. Apabila fungsi bankruptcy remote entity tidak berjalan ketika $S P V$ tidak memiliki asset ataupun arus kas (cash flow) yang cukup, maka akibat hukumnya, para kreditur atau investor akan berusaha memperoleh recovery dari beneficiary yang memperoleh manfaat dari SPV tersebut.

\section{DAFTAR PUSTAKA}

\section{A. Buku}

Badrulzaman, Mariam Darus, 1993, Aspek Hukum Perjanjian Kredit Bank, Citra Adtya Bakti, Bandung.

Black, Henry Campbell, 1996, Black's Law
Dictionary, West Publishng, St. Paul Minn. Bodenheimer, Edgar, et al., 1980, An Introduction to Anglo American Legal System 2nd Edition, American Series, St Paul Minn.

Fabozzi, Frank J., et. al, 2008, "Introduction to 
Mortgage”, Probus Publishing, Chicago.

Hay, Marhainis Abdul, 1985, Perjanjian Kredit, Alumni, Bandung.

Henry, Merryman, John, 2007, The Civil Law Tradition 3rd Edition, Stanford University Press, California.

Isnaeni, H. M., 2018, Hukum Benda dalam Burgerlijke Wetboek, Revka Petra Media, Surabaya.

Isnaeni, H. M., 2018, Pengantar Hukum Jaminan Kebendaan, Riveka Petra Media, Surabaya.

Isnaeni, H. M., 2018, Perjanjian Jual Beli, Riveka Petra Media, Surabaya.

Isnaeni, H. M., 2001, Perjanjian Kredit dan / jjaminan, Bahan Ajar Perkuliahan Perjanjian Kredit dan Jaminan, Program Doktor Progrm Pascasarjana Universitas Arlangga Surabaya.

Raburn, Edward H., dan Roberta Rosenthal Knoll, 1992, Fundamental of Real Poerty Law, The Fundamental Press, New York.

Saragih, Djasadin, 1995, Perbandingan Ilmu Hukum, Bahan Ajar Program Magister Hukum Program Pasca Sarjana Universitas Airlangga.

\section{B. Artikel Jurnal}

Jened, Rahmi, "Perbandingan Hukum Benda Antara Civil Law dan Common Law", Yuridika, Volume 3 Nomor X, Januari - Februari, 1995. Prasetya, Rudhi, dan Neil Hamilton, The Regulation of Indonesian Entreprises, Malaya Law Review, Volume 16, Nomor 2, December, 1974.

\section{Hasil Penelitian/ Tugas Akhir}

Jened, Rahmi, 2012, dkk, Aspek Yuridis Secondary Mortgage Facility Dalam Pembiayaan Perumahan di Indonesia, Laporan Penelitian Dosen muda DP3 M Ditjen DiktiNo. 023/ LIT/ BPPK-SDM/IV/ (Rahmi Jened III).

Prasetya, Rudhi, 2001, Hukum Perseroan dalam Globalisasi Ekonomi, Program Doktor Program Pasca Sarjana, Universitas Airlangga, Surabaya.

\section{Makalah / Pidato}

Direktur Utama PT Persero Sarana Multigriya Finansial, "SMF dan Perkembangannya", Materi Pelatihan, Aspek Hukum Pembiayaan Perumahan dan Sekuritisasi KPR, Kerjasama Program Magister Kenotariatan Fakultas Hukum Universitas Airlangga dengan PT SMF, Surabaya, 6-7 Desember 2014.

Hutagalung, Arie S., "Problema dan Solusi Sistem

Secondary Mortgage Fasility", Seminar,

Perusahaan Secondary Mortgage Facility

Sekunder Perumahan Sebagai Solusi

Pembiayaan Jangka Panjang, Jakarta, 5 November 1998.

Jened, Rahmi, "Perbandingan Hukum Benda Antara

Civil Law dan Common Law", Makalah Tugas Mata Kuliah Djasadin, Program Magister Hukum Program Pasca Sarjana Universitas Airlangga, 1995.

Jened, Rahmi, "Teori Hukum SMF", Pelatihan, Pelatihan SMF Kerjasama PT Sarana Multifinasnsial (Persero) dengan Program Magister Kenotariatan Fakultas Hukum Universitas Airlangga, Surabaya 6-7 Desember 2014.

Suprapto, David, Aspek Hukum Sekuritisasi, Pelatihan Hukum Pembiayaan Perumahan, Kerjasama PT (Persero) SMF dengan Program Kenotariatan Fakultas Hukum Universitas Airlangga, Surabaya, 6-7 Desember 2014.

Suroto, Erica, "Problema dan Solusi Sistem Secondary Mortgage Fasility", Seminar, Perusahaan Secondary Mortgage Facility Sekunder Perumahan Sebagai Solusi Pembiayaan Jangka Panjang, Jakarta, 5 November 1998.

Syahdeini, Remy, "Peranan Jaminan dan Agunan Kredit Menurut UU No. 7/1992 “, Seminar Eksistensi Agunan dan Permasalahannya dalam Perbankan, FH Universitas Surabaya, 1993.

Tanpa nama, "Legal Framework of The Secondary Mortgage Facility", Seminar, Seminat Perusahaan Fasilitas Sekunder Perumahan 
Sebagai Solusi Pembiayaan Jangka Panjang sektor Perumahan, Jakarta, November, 1998.

\section{E. Internet}

Tanpa nama, "Jangan Sampai Mereka Stop Berkarya", kompas.com, diakses 30 Juli 2014.

Tanpa nama, "Kreditur Asing Sayangkan Gugatan

Tri Polyta", hukumonline.com, diakses 30 Juli 2014.

\section{F. Peraturan Perundang-undangan}

Kitab Undang-Undang Hukum Perdata.

Undang-Undang Nomor 4 Tahun 1996 Tentang Hak Tanggungan atas Tanah Beserta Benda-benda yang Berkaitan dengan Tanah (Lembaran Negara Republik Indonesia Tahun 1996 Nomor 42, Tambahan Lembaran Negara Republik Indonesia Nomor 3632).

Peraturan Presiden Nomor 1 Tahun 2008 Tentang Peraturan Presiden Nomor 19 Tahun 2005 tentang Pembiayaan Sekunder Perumahan. 